The Department of Scientific and Industrial Research and most individual research associations issue annual reports packed with matter of interest. These reports, in a condensed form, receive a modified measure of publicity through the Press, which is all to the good. But an annual stimulus, however good, is totally inadequate to keep alive that interest in research work which is so desirable and necessary. In between the issue of these annual reports, much must occur which is of interest to the public. In the spring of this year, the Association of Scientific Workers came to the conclusion that the time is ripe for establishing a Publicity Bureau for the research associations in Great Britain, and circularised the directors of research associations that it was prepared to arrange for free publicity in the Press on all matters referring to research work which were ripe for release. On the whole, the idea was favourably received; and the Bureau has secured a certain amount of publicity for research work. Much more might be accomplished if those in charge of research would bear in mind the desirability of stimulating public interest in their work if public money is to continue to be granted for its maintenance.

\section{Television at the British Association}

During the meeting of the British Association at Leicester, demonstrations of television were given by Baird. Television Ltd. and by Marconi's Wireless Telegraph Co. Ltd. to illustrate the principles employed in television transmission and reception. The latter also showed the use of a light beam system suitable for the transmission of intelligence over short distances. The television transmitter utilised the principle of indirect scanning by means of a beam of light directed on to the subject through a rotating aperture disc. Fifty horizontal scan lines were employed for each picture and the picture repetition frequency was approximately fifteen per second, the whole equipment being designed to enable pictures of moderately good definition to be sent from any high-class broadeasting station. The amplified electric impulses corresponding to the picture signals were made to modulate the light from a special glow discharge tube, containing sodium and a gas filling of neon. This tube was placed at the focus of a mirror fitted in a searchlight mounting, and a concentrated beam of light, carrying the signals as a modulation, was thereby directed towards the receiver.

THe apparatus at the receiving end comprised the necessary optical system for receiving the light beam and extracting from it the modulation signals through the agency of a photoelectric cell. The picture signals received were then amplified and by means of a Kerr cell they were caused to modulate a high intensity arc used as the light source for the projection of the final image. A mirror drum, rotated in synchronism with the scanning dise at the transmitter, was used to project the picture on a white screen, five feet square. The image thus formed can either be reflected from the screen to the audience or it may be viewed by transmitted light through the screen. The latter method was employed in the demonstrations as it was found that increased illumination was obtained in this way. On the last day of the Association's meeting, Major A. G. Church presented an outline of recent developments in television at a special session of Section A (Mathematical and Physical Sciences). On this occasion also the B.B.C. gave a special dual transmission of both television and sound for the benefit of those attending the meeting.

\section{The John Murray Expedition}

ThE John Murray Expedition under Col. R. B. Seymour Sewell (see Nature, May 6, 1933, p. 640) left Alexandria on September 4 in H.E.M.S. Mabahiss for the passage down the Red Sea, during which all apparatus is to be thoroughly tested before arrival at Aden. H.M. King Fuad received Col. Sewell and his chief officers and expressed his pleasure in having been able to lend the Mabahiss for the Expedition. $\mathrm{He}$ showed himself keenly interested inand wellacquainted with the scientific problems under investigation. A farewell reception at which the Prime Minister and many high Government officials were present was also given by the Director General of the Indian Marine, El Miralai Ahmed Fuad Bey, on board H.E.M.S. El Almira Fauzia. In his eloquent speech he referred to the veneration which is felt by oceanographers of all countries for the name of Sir John Murray and the satisfaction felt in Egypt that "East and West have met in the pursuit of the unknown". He urged the Fgyptian personnel to do their best to bring back practical "experience and wide knowledge" for the service of their country, adding "honour to Egypt" and reminding them that "countries are known by their countrymen". Afterwards an inspection was made of the Mabahiss which has been fitted with the Hughes Admiralty sounding gear and refrigeration in the Naval Dockyard. The fish hold and scientific quarters have also been largely remodelled so as to give a good chemical laboratory, more cabins and special storage space, while the sides of the deck were picturesque with the trawls, dredges, etc. lashed thereto.

\section{Antiquity of Man in America}

RECENT excavations by an expedition of the University of Pennsylvania Museum and the Philadelphia Academy of Natural Sciences at Clovis, New Mexico, under the field direction of Mr. Edgar B. Howard, have brought to light masses of bones of mammoth and of extinct species of horse and bison, together with what are thought to be camel bones, in old lake beds. Although no human bones have been found, numbers of stone spear-points, knives and scrapers have been found in the same beds, not far from the animal remains. Farlier excavations by Mr. Howard in a cave near Carlsbad, New Mexico, revealed hearths at varying depths down to eight. feet, with the bones of musk-ox and bison, which had been used for food. Stone spear-points were also found among the debris of the hearths. The evidence from the two sites is taken as lending further support to the view, which is gaining ground among 